\title{
Development of Glutamatergic Proteins in Human Visual Cortex across the Lifespan
}

\author{
(DCaitlin R. Siu, ${ }^{1 \star}$ Simon P. Beshara, ${ }^{1 \star}$ (DDavid G. Jones, ${ }^{2}$ and ${ }^{\circ}$ Kathryn M. Murphy ${ }^{1,3}$ \\ ${ }^{1}$ McMaster Integrative Neuroscience Discovery and Study Program, McMaster University, Hamilton, Ontario L8S 4K1, Canada, ${ }^{2}$ Pairwise Affinity Inc, \\ Dundas, Ontario L9H 2R9, Canada, and '3Department of Psychology, Neuroscience and Behaviour, McMaster University, Hamilton, Ontario L8S 4K1, \\ Canada
}

Traditionally, human primary visual cortex (V1) has been thought to mature within the first few years of life, based on anatomical studies of synapse formation, and establishment of intracortical and intercortical connections. Human vision, however, develops well beyond the first few years. Previously, we found prolonged development of some GABAergic proteins in human V1 (Pinto et al., 2010). Yet as $>80 \%$ of synapses in V1 are excitatory, it remains unanswered whether the majority of synapses regulating experience-dependent plasticity and receptive field properties develop late, like their inhibitory counterparts. To address this question, we used Western blotting of postmortem tissue from human V1 (12 female, 18 male) covering a range of ages. Then we quantified a set of postsynaptic glutamatergic proteins (PSD-95, GluA2, GluN1, GluN2A, GluN2B), calculated indices for functional pairs that are developmentally regulated (GluA2:GluN1; GluN2A:GluN2B), and determined interindividual variability. We found early loss of GluN1, prolonged development of PSD-95 and GluA2 into late childhood, protracted development of GluN2A until 40 years, and dramatic loss of GluN2A in aging. The GluA2:GluN1 index switched at $\sim 1$ year, but the GluN2A:GluN2B index continued to shift until $\sim 40$ year before changing back to GluN2B in aging. We also identified young childhood as a stage of heightened interindividual variability. The changes show that human V1 develops gradually through a series of five orchestrated stages, making it likely that V1 participates in visual development and plasticity across the lifespan.

Key words: development; glutamate; human; receptors; synaptic proteins; visual cortex

Significance Statement

Anatomical structure of human V1 appears to mature early, but vision changes across the lifespan. This discrepancy has fostered two hypotheses: either other aspects of V1 continue changing, or later changes in visual perception depend on extrastriate areas. Previously, we showed that some GABAergic synaptic proteins change across the lifespan, but most synapses in V1 are excitatory leaving unanswered how they change. So we studied expression of glutamatergic proteins in human V1 to determine their development. Here we report prolonged maturation of glutamatergic proteins, with five stages that map onto life-long changes in human visual perception. Thus, the apparent discrepancy between development of structure and function may be explained by life-long synaptic changes in human V1.

\section{Introduction}

Anatomical development of human visual cortex (V1) proceeds quickly over the first few years (Huttenlocher et al., 1982; Zilles et

\footnotetext{
Received July 20, 2016; revised April 30, 2017; accepted May 3, 2017.

Author contributions: C.R.S., S.P.B., and K.M.M. designed research; C.R.S., S.P.B., and K.M.M. performed research; D.G.J. contributed unpublished reagents/analytic tools; C.R.S., S.P.B., D.G.J., and K.M.M. analyzed data; C.R.S., S.P.B., D.G.J., and K.M.M. wrote the paper.

This work was supported by Natural Sciences and Engineering Research Council Grant RGPIN-2015-06215 to K.M.M., Woodburn Heron OGS to C.R.S., Natural Sciences and Engineering Research Council PGS to S.P.B., and OCE to D.G.J. Wethank Kyle Hornby and Dr Joshua Pinto for technical help; and Justin Balsor for comments on the manuscript.

The authors declare no competing financial interests.

*C.R.S. and S.P.B. contributed equally to this work.

Correspondence should be addressed to Dr. Kathryn M. Murphy, Department of Psychology Neuroscience and Behaviour, McMaster University, 1280 Main Street West, Hamilton, Ontario L8S 4K1, Canada. E-mail: kmurphy@mcmaster.ca.
}

al., 1986; Burkhalter, 1993; Burkhalter et al., 1993), but maturation of vision is slow, changing through childhood, adolescence, adulthood, and aging (Kovács et al., 1999; Lewis and Maurer, 2005; Germine et al., 2011; Owsley, 2011). The discrepancy between development of structure and function led to the idea that prolonged maturation of vision might depend on features of V1 not captured by anatomical studies (Taylor et al., 2014). For example, some GABAergic and myelin proteins involved with plasticity continue developing into adulthood in human V1 (Pinto et al., 2010; Siu et al., 2015). Most V1 synapses, however, are excitatory (Beaulieu et al., 1992) and glutamatergic receptors regulate

DOI:10.1523/JNEUROSCI.2304-16.2017

Copyright $\odot 2017$ the authors $\quad 0270-6474 / 17 / 376031-12 \$ 15.00 / 0$ 
experience-dependent plasticity (Hensch, 2004; Turrigiano and Nelson, 2004; Cooper and Bear, 2012; Levelt and Hübener, 2012) and receptive field properties (Ramoa et al., 2001; Rivadulla et al., 2001; Fagiolini et al., 2004; Self et al., 2012). Currently, little is known about expression of glutamatergic proteins in human V1 (Huntley et al., 1994; Scherzer et al., 1998) and less about how they change across the lifespan (Pinto et al., 2015).

Animal models found that activation of glutamate receptors, NMDA and AMPA, regulates plasticity in V1 (Kleinschmidt et al., 1987; Daw et al., 1992; Turrigiano and Nelson, 2004; Yashiro and Philpot, 2008; Smith et al., 2009; Cooke and Bear, 2014; Turrigiano, 2017). The recruitment of AMPARs to silent synapses starts the critical period (CP) (Rumpel et al., 1998) and an increase in the glutamate receptor scaffolding protein, PSD-95, consolidates synapses to end the CP (Huang et al., 2015). The composition of AMPARs and NMDARs regulates juvenile ocular dominance plasticity starting with weakening of deprived eye responses by the rapid loss of GluA2 (Heynen et al., 2003; Lambo and Turrigiano, 2013) and increase of GluN2B (Chen and Bear, 2007). Next, open eye responses are strengthened by an increase of GluA2 (Lambo and Turrigiano, 2013) and decrease of GluN2A (Smith et al., 2009). The developmental shift from more GluN2B to more GluN2A (2A:2B balance) regulates metaplasticity because GluN2B allows more $\mathrm{Ca}^{2+}$ to enter the synapse and activate LTP mechanisms (Yashiro and Philpot, 2008). The 2A:2B balance shifts during the CP (Sheng et al., 1994) when visual experience drives a loss of GluN2B (Philpot et al., 2001), an increase of GluN2A (Quinlan et al., 1999a, b), and reduces ocular dominance plasticity (Philpot et al., 2003, 2007).

Receptive field properties in V1 are also regulated by glutamate receptors. The dense expression of glutamate receptors in layers 2/3 and 4 (Huntley et al., 1994; Kooijmans et al., 2014) supports AMPARs dominated feedforward and NMDARs dominated feedback drive (Self et al., 2012). Furthermore, development of orientation preference is prevented by suppressing NMDARs (Ramoa et al., 2001) and requires the GluN2A subunit (Fagiolini et al., 2003).

Here, we investigate development of glutamate receptors in human V1 (PSD-95, GluN1, GluN2A, GluN2B, and GluA2) from birth to 80 years of age. We find changes that could contribute to visual processing and plasticity throughout the lifespan.

\section{Materials and Methods}

Samples. The postmortem tissue samples from human visual cortex used in this study were obtained from the Brain and Tissue Bank for Developmental Disorders at the University of Maryland (Baltimore) and the study was approved by the McMaster University Research Ethics Board. Cortical samples were from individuals with no history of brain disorders, and all causes of death were with minimal trauma. Samples were collected within $23 \mathrm{~h}$ postmortem, sectioned coronally in $1 \mathrm{~cm}$ intervals, flash frozen at the Brain and Tissue Bank, and stored at $-80^{\circ} \mathrm{C}$. Visual cortex samples were taken from the posterior pole of the left hemisphere and included both superior and inferior portions of the calcarine fissure. A total of 30 cases were used and ranged in age from $20 \mathrm{~d}$ to 79 years (Table 1).

Sample preparation. A small piece of tissue (50-100 mg) was cut from the calcarine fissure of each frozen block of human V1, suspended in cold homogenization buffer ( $1 \mathrm{ml}$ buffer: $50 \mathrm{mg}$ tissue, $0.5 \mathrm{~mm}$ DTT, $2 \mathrm{~mm}$ EDTA, 2 mм EGTA, 10 mm HEPES, 10 mg/L leupeptin, 100 nм microcystin, $0.1 \mathrm{~mm}$ PMSF, $50 \mathrm{mg} / \mathrm{L}$ soybean trypsin inhibitor), and homogenized in a glass-glass Dounce hand homogenizer (Kontes). To enrich for synaptic proteins, we used a synaptosome preparation. Homogenate samples were filtered through coarse $(100 \mu \mathrm{g})$ and fine $(5 \mu \mathrm{g})$ pore hydrophilic mesh filters (Millipore), and then centrifuged at $1000 \times g$ for
Table 1. Human V1 tissue samples ${ }^{a}$

\begin{tabular}{|c|c|c|c|}
\hline Age & Age group & Sex & PMI (hr) \\
\hline $20 d$ & Neonate & Male & 9 \\
\hline $86 d$ & Neonate & Female & 23 \\
\hline $96 d$ & Neonate & Male & 12 \\
\hline $98 d$ & Neonate & Male & 16 \\
\hline $119 d$ & Neonate & Male & 22 \\
\hline $120 d$ & Neonate & Male & 23 \\
\hline $133 d$ & Infant & Male & 16 \\
\hline $136 d$ & Infant & Female & 11 \\
\hline $273 d$ & Infant & Male & 10 \\
\hline 1 yr 123 d & Young children & Male & 21 \\
\hline $2 \operatorname{yr} 57 d$ & Young children & Female & 21 \\
\hline $2 \mathrm{yr} 75 \mathrm{~d}$ & Young children & Female & 11 \\
\hline 3 yr $123 d$ & Young children & Female & 11 \\
\hline 4 yr 203 d & Young children & Male & 15 \\
\hline 4 yr $258 d$ & Young children & Male & 17 \\
\hline 5 yr 144 d & Older children & Male & 17 \\
\hline $8 \mathrm{yr} 50 \mathrm{~d}$ & Older children & Female & 20 \\
\hline 8 yr 214 d & Older children & Female & 20 \\
\hline $9 \mathrm{yr} 46 \mathrm{~d}$ & Older children & Female & 20 \\
\hline $12 \mathrm{yr} 164 \mathrm{~d}$ & Teens & Male & 22 \\
\hline 13 yr $99 \mathrm{~d}$ & Teens & Male & 5 \\
\hline $15 \mathrm{yr} 81 \mathrm{~d}$ & Teens & Male & 16 \\
\hline $19 \mathrm{yr} 76 \mathrm{~d}$ & Teens & Female & 16 \\
\hline $22 \mathrm{yr} 359 \mathrm{~d}$ & Young adults & Male & 4 \\
\hline $32 \mathrm{yr} 223 \mathrm{~d}$ & Young adults & Male & 13 \\
\hline $50 \mathrm{yr} 156 \mathrm{~d}$ & Young adults & Male & 8 \\
\hline $53 \mathrm{yr} 330 \mathrm{~d}$ & Young adults & Female & 5 \\
\hline $69 \mathrm{yr} 110 \mathrm{~d}$ & Older adults & Male & 12 \\
\hline 71 yr $333 \mathrm{~d}$ & Older adults & Female & 9 \\
\hline $79 \mathrm{yr} 181 \mathrm{~d}$ & Older adults & Female & 14 \\
\hline
\end{tabular}

${ }^{a}$ Each case is identified by their age in years and days, age group assignment, sex, and PMI.

$10 \mathrm{~min}$ to obtain the synaptic fraction. The synaptosome pellet was resuspended in boiling $1 \%$ SDS, heated for $10 \mathrm{~min}$, and stored at $-80^{\circ} \mathrm{C}$.

Synaptosome protein measurement and equating. Low abundance synaptic proteins are enriched threefold to fivefold by the synaptosome preparation (Murphy et al., 2014), which facilitates the reliable detection of synaptic proteins by Western blot analysis. In contrast, housekeeping proteins used as loading controls, such as GAPDH or $\beta$-tubulin, are reduced approximately 10 -fold in a synaptosome preparation because the small synaptosome volume is dominated by synaptic proteins (Balsor and K.M.M., unpublished observation). Moreover, those loading controls are known to exhibit high variability (Lee et al., 2016) and change under many conditions, including experience (Dahlhaus et al., 2011) and development (Pinto et al., 2015). For these reasons, normalizing an enriched synaptosome preparation with a diminished loading control can lead to the undesirable outcome of inflating the apparent expression of synaptic proteins, especially early in development. It is important, however, for Western blot analyses to accurately quantify total protein and to load equivalent amounts. To achieve these, we used a stringent 3 stage protocol to measure and equate protein concentrations among the samples and then load equivalent volumes into each gel.

To measure and equate protein concentration for each synaptosome sample, we used a BCA assay (Pierce, ThermoFisher Scientific) and compared the samples with a set of protein standards $(0.25,0.5,1.0,2.0$ $\mathrm{mg} / \mathrm{ml}$ ) (BSA protein standards, Bio-Rad Laboratories). We mixed a small amount of each sample and standard $(9 \mu \mathrm{l})$ with BCA assay solution (1:100), and loaded 3 aliquots (each $300 \mu \mathrm{l}$ ) into separate wells of a 96-well microplate. The plate was incubated at $45^{\circ} \mathrm{C}$ for $45 \mathrm{~min}$ to activate the reaction, then scanned in an iMark Microplate Absorbance Reader (Bio-Rad Laboratories) to quantify the colorimetric change. Next, we plotted the absorbance values of the standards relative to their known concentrations, and fit a linear correlation to the data. The fit for the correlation had to be $R^{2}>0.99$; and if it did not reach that level, the BCA assay was rerun. The absorbance of the human samples was measured and averaged for the 3 aliquots. This sample absorbance value and 
the linear equation fit to the standards were used to determine the amount of Laemmli buffer (Cayman Chemical) and sample buffer (M260 Next Gel Sample loading buffer $4 \times$, Amresco) needed to achieve protein concentrations of $1 \mu \mathrm{g} / \mu \mathrm{l}$. Finally, to ensure loading of equivalent volumes into each well of the gel, we used a high-quality pipette (e.g., Picus, Sartorius) and performed regular calibrations.

Immunoblotting. Synaptosome samples $(20 \mu \mathrm{g})$ were separated on $4 \%-$ 20\% SDS-PAGE and transferred to PVDF membranes (Immobilon-FL PVDF, EMD Millipore). Each sample was run multiple times, and a control sample, made by combining a small amount of the synaptosome preparation from each of the 30 cases, was run on each gel. Blots were preincubated in blocking buffer for $1 \mathrm{~h}$ (Odyssey Blocking Buffer 1:1 with PBS) (Li-Cor Biosciences), then incubated in primary antibody overnight at $4^{\circ} \mathrm{C}$ using these primary antibodies: anti-NMDAR1, 1:4000 (RRID: AB_396353, BD Biosciences PharMingen); anti-NR2A, 1:1000 (RRID: AB_95169, EMD Millipore); anti-NMDAR2B, 1:1000 (RRID: AB_2112925, EMD Millipore); anti-GluA2, 1:1000 (RRID: AB_2533058, Invitrogen); and anti-PSD95, 1:16000 (RRID: AB_94278, EMD Millipore). These antibodies were selected after testing them on a multispecies blot that included samples from human, monkey, cat, and rat to ensure that the human samples had bands comparable with the other species. The blots were washed with PBS-Tween $(0.05 \%$ PBS-T, Sigma) $(3 \times 10 \mathrm{~min})$ and incubated for $1 \mathrm{~h}$ at room temperature with the appropriate IRDye labeled secondary antibody (anti-mouse, 1:8000, RRID: AB_10956588; anti-rabbit, 1:10,000, RRID: AB_621843; Li-Cor Biosciences), and washed again in PBS-Tween $(3 \times 10 \mathrm{~min})$. The bands were visualized using the Odyssey scanner (Li-Cor Biosciences), and we determined that the amount of protein loaded into each well and the antibody concentrations were within the linear range of the Odyssey scanner. After scanning, the blots were stripped using a Blot Restore Membrane Rejuvenation Kit (EMD Millipore), rescanned to ensure complete stripping, and then reprobed with another antibody.

Band analysis. To analyze the bands, blots were scanned on an Odyssey infrared scanner and quantified using densitometry (Odyssey Software version 3.0; Li-Cor Biosciences). A density profile for each band was calculated by performing a subtraction of the background, integrating the pixel intensity across the area of the band, and dividing the intensity by the width of the band to control for variations in lane width. A control sample, made by combining a small amount from each sample, was run on each gel, and the density of each sample was quantified relative to the control (sample density/control density).

Band image manipulation. Bands shown on figures are representative samples and were added to the figures in Photoshop (Adobe Systems, RRID:SCR_014199). Horizontal and vertical transformations were applied to size and orient the bands for each figure. A linear adjustment layer was applied uniformly to all bands for each protein, preserving the relative intensities among bands.

Receptor subunit index. To quantify the balance between functional pairs of proteins, we calculated a difference ratio, often called a contrast index, that is commonly used in signal processing to determine the quality of a signal. We calculated two indices that reflect the balance between pairs of proteins that are developmentally regulated: AMPA:NMDA index, (GluA2 - GluN1)/(GluA2 + GluN1); and NMDAR subunit 2A:2B index, (GluN2A - GluN2B)/(GluN2B + GluN2A). These indices can have values between -1 and 1 .

Curve-fitting and statistical analyses. The results were plotted in two ways to visualize and analyze changes in expression across the lifespan. First, to describe the time course of changes in protein expression, scatterplots were made for each protein showing the expression level from each run (gray dots) and the average of the runs (black dots). To determine the trajectory of changes across the lifespan, we used a model-fitting approach (Christopoulos and Lew, 2000) and found the best curve-fit to the data using MATLAB (The MathWorks, RRID: SCR_001622). A single-exponential decay function $(\mathrm{Y}=\mathrm{A} \times \exp (-(\mathrm{x} / \tau))+\mathrm{B})$ was fit to the data for GluN1. A Gaussian function $\left(\mathrm{Y}=\mathrm{A} \times \exp \left(-\left(\left(\log (\mathrm{x} / \mu)^{2}\right) /\right.\right.\right.$ $\left.\left.\left(2 \times\left(\sigma^{2}\right)\right)\right)+B\right)$ was fit to the data for PSD-95, GluA2, GluN2B, and the $2 \mathrm{~A}: 2 \mathrm{~B}$ index. A quadratic function was fit to the AMPA:NMDA balance $\left(\mathrm{Y}=\mathrm{A}+\mathrm{B} \times \log (\mathrm{x})+\mathrm{C} \times \log (\mathrm{x})^{2}\right)$. Finally, a weighted average was used to describe the trajectory for GluN2A. The fits were found by least squares, and the goodness-of-fit $\left(R^{2}\right)$ and statistical significance of the fit
( $p$ ) were determined. For the decay function, we calculated the time constants $(\tau)$ and defined $3 \tau$ (when $87.5 \%$ of the change in expression had occurred) as the age when mature expression was reached with the 95\% CI around that age. For Gaussian functions, the age at the peak was calculated and the $95 \%$ CI determined.

Second, to compare changes among different stages across the lifespan, samples were binned into age groups $(<0.3$ years, Neonates; $0.3-1$ year, Infants; 1-4 years, Young Children; $5-11$ years, Older Children; 12-20 years, Teens; 21-55 years, Young Adults; $>55$ years, Older Adults), and histograms were plotted showing the mean and SEM for each group. We used bootstrapping to make statistical comparisons among the groups because this method provides robust estimates of SE and CI, which are especially useful for human studies constrained to smaller sample sizes. The statistical software R (R Core Team, 2014, R: A language and environment for statistical computing. R Foundation for Statistical Computing, http://www.R-project.org, RRID: SCR_001905) was used for the bootstrapping, and we began by simulating a normally distributed dataset (1,000,000 points) with the same mean and SD of the group being compared. We used this normally distributed dataset to determine whether the observed means for the other age groups were significantly different. A Monte Carlo simulation was used to randomly sample from the simulated dataset $N$ times, where $N$ was the number of cases in the other age groups. This simulation was run 10,000 times to generate an expected distribution for the $N$ number of cases. CIs were calculated for that simulated distribution (i.e., 95\%, 99\% CI) and compared with the observed group means. The age groups were considered to be significantly different (i.e., $p<0.05$ ) when the observed mean was outside the $95 \%$ CI.

Analysis of interindividual variability. Previously, we identified ages during infancy and childhood with waves of high interindividual variability (Pinto et al., 2015; Siu et al., 2015). To analyze whether the glutamatergic proteins studied here have similar waves of interindividual variability we calculated the Fano factor (variance-to-mean ratio [VMR]) for each protein and examined how it changed across the lifespan. The VMR around each case was determined by calculating the mean and variance for the protein expression within a moving box that included three adjacent ages and then dividing the variance by the mean. Scatterplots were made to show how the VMRs changed across the life span, and functions were fit to those data to identify ages when there was high interindividual variability. The VMRs were fit with the same Gaussian function described above, and a wave of higher interindividual variability was identified when 4 or more points at the peak fell above the $95 \%$ CI for lower bound of the curve.

\section{Results}

\section{Postmortem interval}

We examined whether glutamate protein expression levels were affected by postmortem interval (PMI). First, we verified that immunoreactivity was present and then analyzed the correlation between PMI and protein expression. There were no significant correlations between PMI and expression of the five glutamatergic proteins (PSD-95: $r=0.05, p=0.66$; GluA2: $r=0.17, p=$ 0.13; GluN1: $r=0.26, p=0.11$; GluN2A: $r=0.17, p=0.41$; GluN2B: $r=0.16, p=0.24$ ), so all of the data were included in the following analyses.

\section{Slow development of PSD-95, earlier but opposite development of GluA2 and GluN1}

We began analyzing development of glutamate proteins in human V1 by measuring expression of PSD-95, a scaffolding protein involved in anchoring AMPA and NMDA receptors (Kim and Sheng, 2004), controlling visual developmental plasticity (Yoshii et al., 2003), and ending the CP for ocular dominance plasticity (Huang et al., 2015). We found a steady increase in expression of PSD-95 in the synaptosome preparation used in this study and analyzed the results in two ways (Fig. 1): (1) by model fitting to all the data to determine the best curve to capture changes across the lifespan; and (2) by binning the data into age 
A

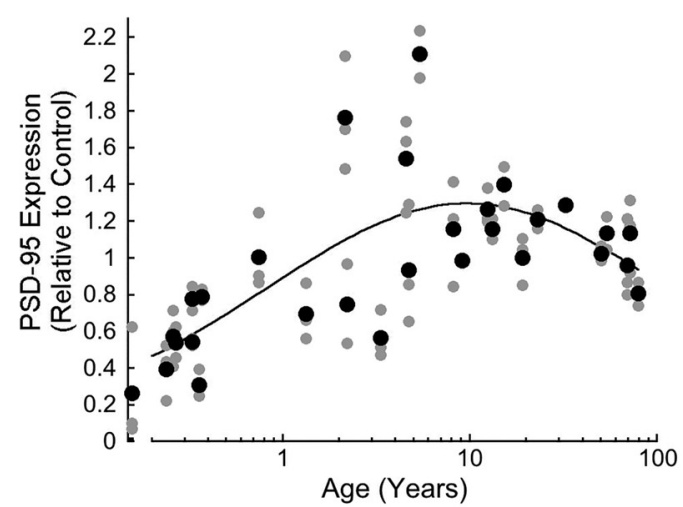

C

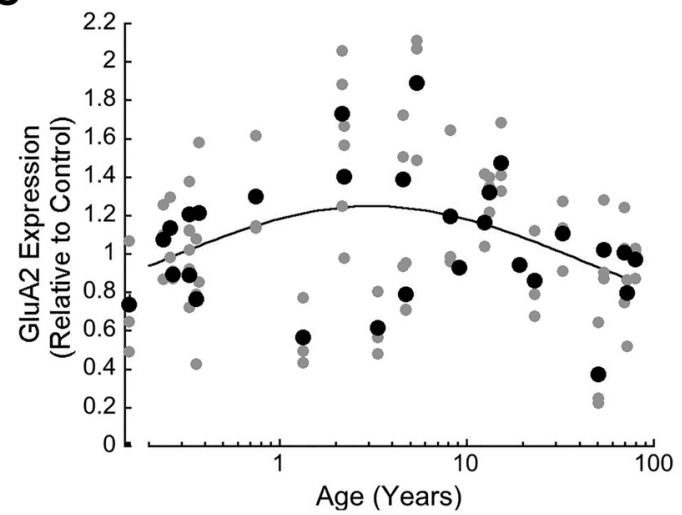

E

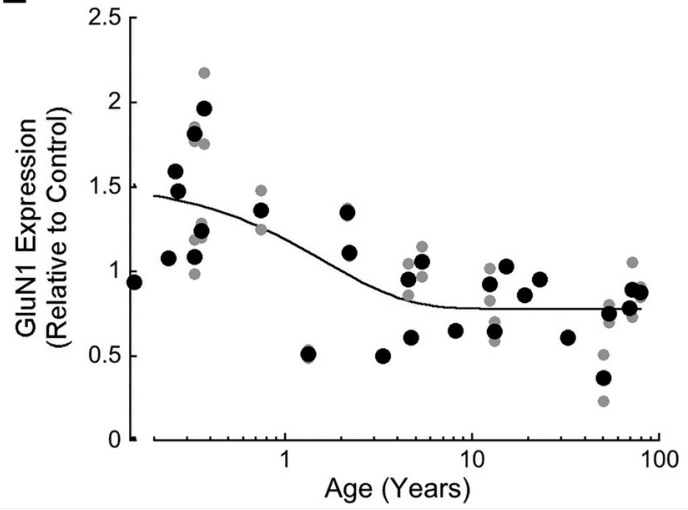

B

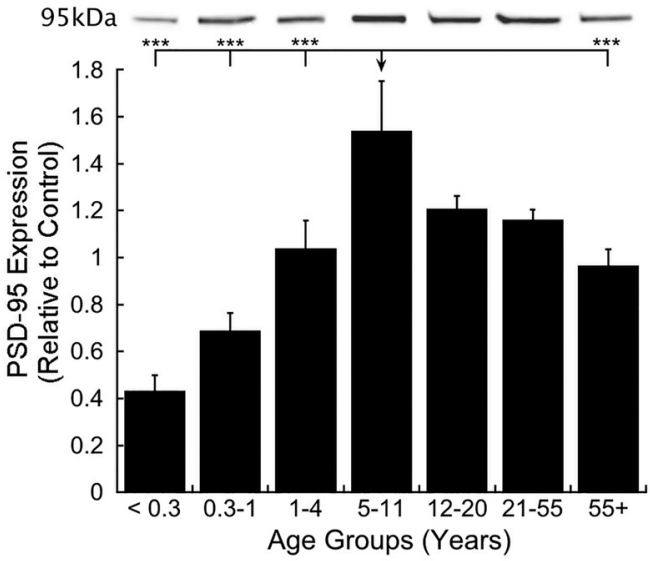

D

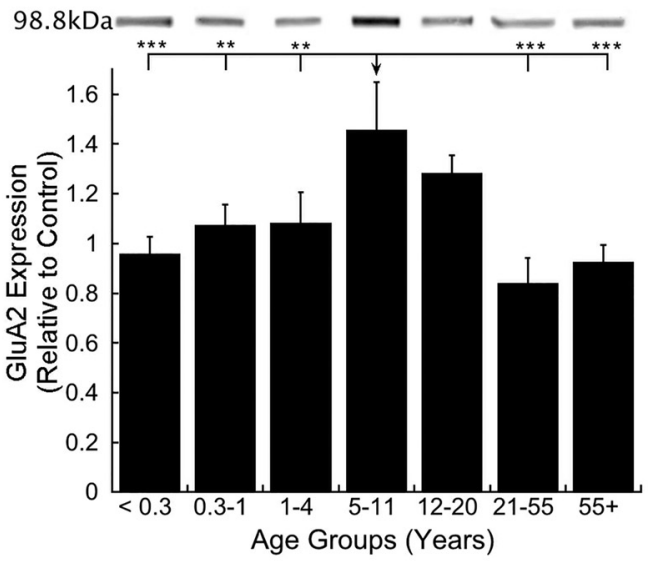

$\mathbf{F}$

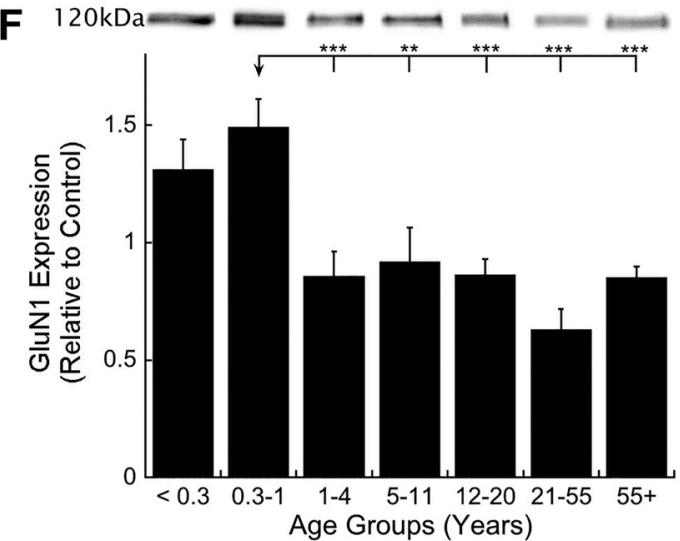

Figure 1. Development of PSD-95, GluA2, and GluN1 expression in human V1. $A$, Scatterplot of PSD-95 expression across the lifespan fit with a Gaussian function $\left(R^{2}=0.457, p<0.0001\right)$ with peak expression at 9.6 years ( \pm 4.1 years). $B$, Age-binned results for PSD-95 expression. C, Scatterplot of GluA2 expression across the lifespan fit with a Gaussian function $\left(R^{2}=0.131, p<0.01\right)$, with peak expression at 3.1 years $\left( \pm 1.8\right.$ years). $\boldsymbol{D}$, Age-binned results for $G$ luA2 expression. $\boldsymbol{E}$, Scatterplot of GluN1 expression across the lifespan fit with an exponential decay function $\left(R^{2}=0.482\right.$, $p<0.0001)$ and fell to mature levels $(3 \tau)$ at 4.2 years $( \pm 1.7$ years). $\boldsymbol{F}$, Age-binned results for GluN1 expression. For the scatterplots, gray dots represent each run and black dots represent the average for each case; age was plotted on a logarithmic scale. For the histograms, protein expression was binned into age groups ( $<0.3$ years, Neonates; $0.3-1$ year, Infants; $1-4$ years, Young Children; 5-11 years, Older Children; $12-20$ years, Teens; $21-55$ years, Young Adults; $>55$ years, Older Adults), showing the mean and SEM. Representative bands are shown above each age group. ${ }^{* *} p<0.01$. ${ }^{* *} p<0.001$.

groups and using bootstrapping for statistical comparisons between groups. Development of PSD-95 peaked at 9.6 years $( \pm 4.1$ years; $R^{2}=0.457, p<0.0001$ ) (Fig. $1 A$ ). This result was similar to our previous findings using whole homogenate samples (Pinto et al., 2015). The magnitude of the peak in the synaptosome, however, was approximately half that found using the whole homogenate (Pinto et al., 2015) (see Fig. 3), suggesting there could be a large mobile pool of PSD-95 during late childhood. Comparing the age-binned results showed a threefold increase in PSD-95 expression during development that reached a peak in older children (5-11 years, $p<0.001$ ) before dropping $\sim 30 \%$ into aging $(p<0.001)$ (Fig. 1B). The PSD-95 peak corresponded with the age when children are no longer susceptible to amblyopia (Lewis and Maurer, 2005) and may signify that PSD-95 contributes to ending the $\mathrm{CP}$ for ocular dominance plasticity in humans similar to its role in rat V1 (Huang et al., 2015). 

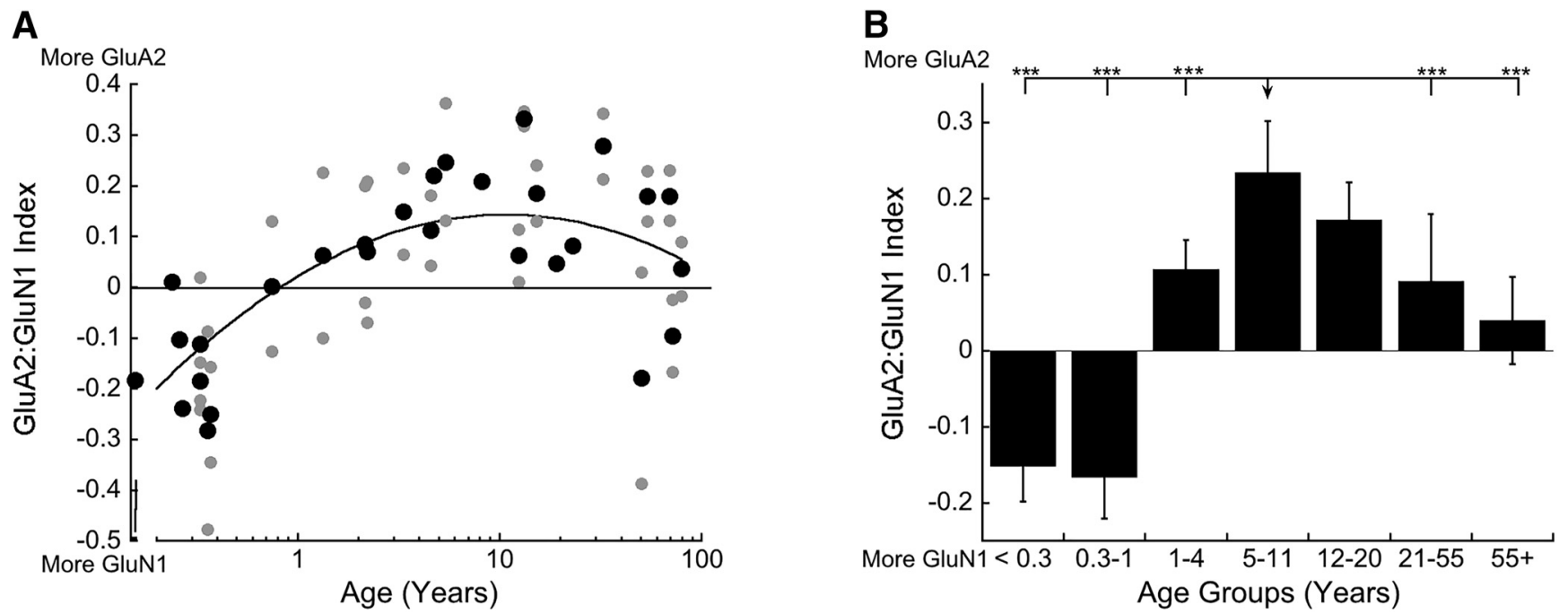

Figure 2. Development of the AMPA:NMDA balance ((GluA2 - GluN1)/(GluA2 + GluN1)) in human V1. A, Scatterplot of the AMPA:NMDA balance across the lifespan fit with a quadratic function $\left(R^{2}=0.406, p<0.0001\right)$, which peaked at 10.7 years $(95 \%$ Cl, $4.8-23.7$ years). $\boldsymbol{B}$, Age-binned results for the AMPA:NMDA balance. Scatterplot, histogram, and significance levels plotted using the conventions described in Figure $1 .{ }^{* * *} p<0.001$.

Next, we quantified development of GluA2 and GluN1, which identify the two main classes of ionotropic glutamate receptors AMPARs and NMDARs, respectively. Development of these subunits followed a similar pattern to that found in animal studies, where GluA2 increased, whereas GluN1 decreased during development (Fig. 1C-F). GluA2 expression increased $\sim 40 \%$ during childhood and then declined a similar amount into adulthood and aging. The GluA2 developmental trajectory peaked at 3.1 years $\left( \pm 1.8\right.$ years, $R^{2}=0.131, p<0.01$ ) (Fig. $1 C$ ). Comparison of GluA2 expression among the age groups, however, identified a slightly later peak during late childhood (5-11 years) (Fig. 1D). The uncertainty about the peak for GluA2 probably reflects variability in expression during childhood and the modest increase between neonates and older children.

The trajectory of GluN1 expression started high $<1$ year of age and then rapidly decreased to a relatively constant level for the rest of the lifespan (Fig. 1E,F). The change in GluN1 expression was fit with an exponential decay function $\left(R^{2}=\right.$ $0.482, p<0.0001)$ that fell to mature levels $(3 \tau)$ by 4.2 years ( \pm 1.7 years) (Fig. $1 E$ ). The same pattern was found when we compared among age groups where GluN1 levels were higher $<1$ year and dropped by almost half during young childhood $(1-4$ years $)(p<0.001)$ and remained at that level for the rest of the lifespan (Fig. $1 F$ ).

Comparing the changes across the lifespan for PSD-95, GluA2, and GluN1, we found different timing (GluA2 and GluN1 matured before PSD-95), different directions (PSD-95 and GluA2 increased while GluN1 decreased), and different amounts of protein change. Thus, even these three tightly associated proteins had different developmental trajectories.

\section{Early shift from more NMDA to more AMPA in human V1}

Animal studies have shown that there is an early developmental shift from NMDAR-dominated silent synapses to functional synapses with AMPARs (Isaac et al., 1997; Rumpel et al., 1998). Here we examined development of the AMPA:NMDA balance in human V1 as an indication of functional maturation of glutamatergic transmission. We calculated an AMPA:NMDA index where a value of -1 indicated only GluN1 expression, 0 indicated equal expression, and 1 indicated only GluA2 expression. We found an early switch from more GluN1 $<1$ year of age to more GluA2 after 1 year (Fig. 2). The AMPA:NMDA balance was fit with a quadratic function $\left(R^{2}=0.406, p<0.0001\right)$ that captured the shift from GluN1 to GluA2 that peaked at 10.7 years (95\% CI, $4.8-23.7$ years) before slowly returning to equal expression during aging (Fig. 2A). The age-binned results showed the same pattern of a significant switch at 1 year, GluA2 peaking during late childhood, and returning to balanced expression in older adults (Fig. 2B). The changes in this AMPA:NMDA balance suggest an early stage of human $\mathrm{V} 1$ development during infancy ( $<1$ year) that may characterize unsilencing of glutamate synapses followed by AMPAR dominated excitatory drive during childhood and young adults before regressing to balanced AMPAR and NMDAR expression in aging.

\section{GluN2A and GluN2B subunit expression in human V1}

We examined developmental changes in expression of 2 NMDAR subunits, GluN2A and GluN2B, because they affect development of receptive field tuning and ocular dominance plasticity. In particular, the rise of GluN2A and concomitant loss of GluN2B during the $\mathrm{CP}$ is one mechanism that causes reduced ocular dominance plasticity in adult cortex (Philpot et al., 2007). The scatterplot of GluN2B expression showed a modest peak during childhood and relatively constant expression through teens, young adults, and older adults (Fig. $3 A, B$ ). The GluN2B trajectory was fit by a Gaussian function $\left(R^{2}=0.176, p<0.01\right)$ that peaked at 1.2 years ( \pm 0.7 years) (Fig. $3 A)$. We compared GluN2B expression among the age groups and found higher levels during childhood (5-11 years) relative to teens, young adults, and older adults (Fig. $3 B)(p<0.01)$.

The developmental trajectory for GluN2A was different from GluN2B. Initially, GluN2A expression was low, then variable during childhood and teenage years ( 8 cases with low and 3 cases with high GluN2A expression) followed by high expression in young adults and ending with a large $(\sim 75 \%)$ decline into aging. The variability during childhood reduced the goodness-of-fit for a Gaussian function, so instead we plotted a descriptive weighted curve (Fig. $3 C$ ). Interestingly, the 3 childhood cases with high GluN2A expression also had high GluN2B expression. Binning the results into age groups showed that young adults had more 
A

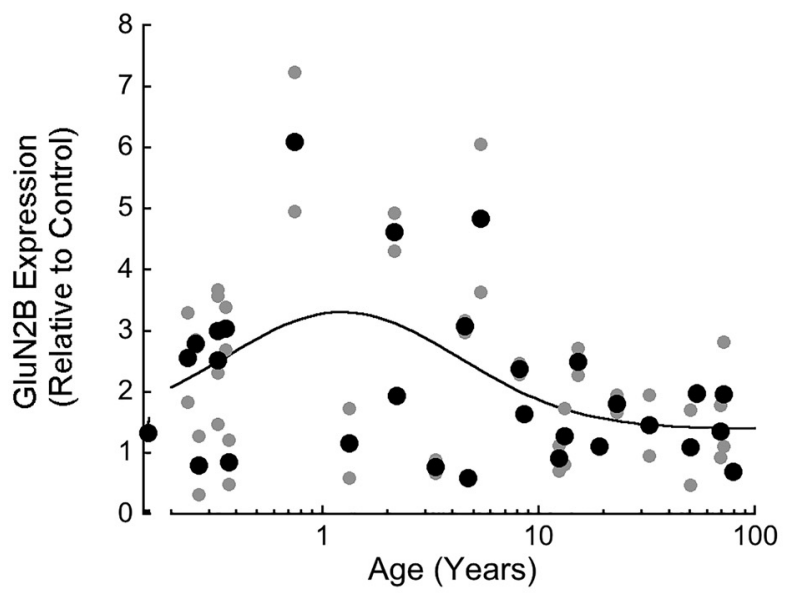

C

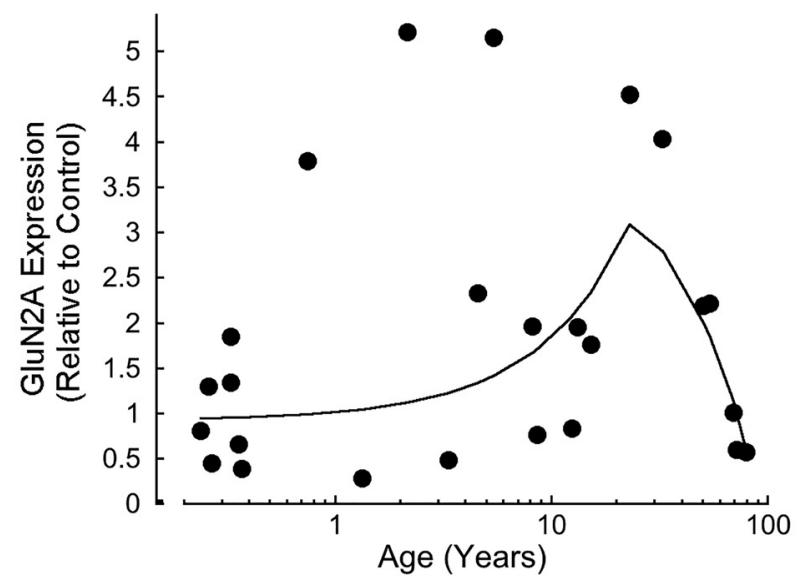

B
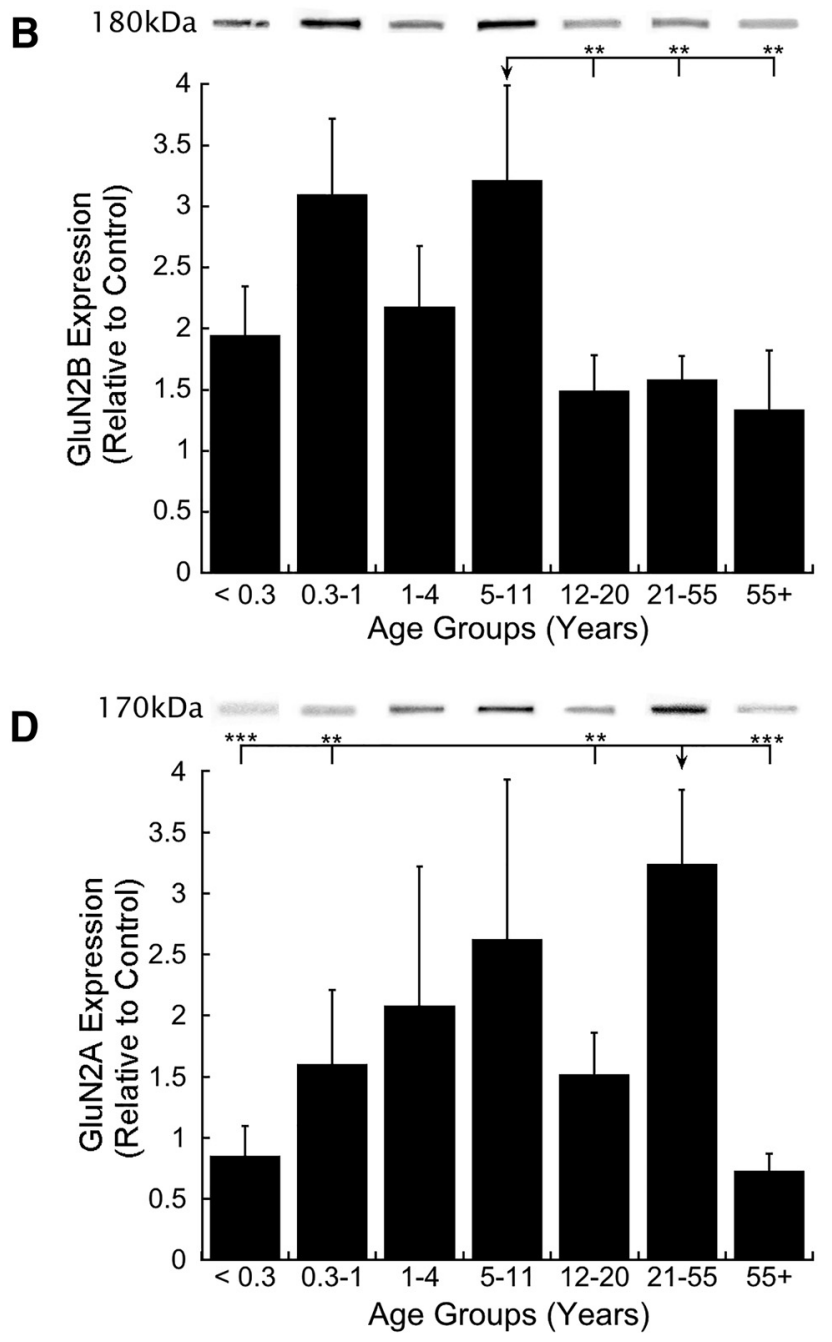

Figure 3. Development of GluN2B and GluN2A in human V1. $A$, Scatterplot of GluN2B expression across the lifespan fit with a Gaussian function $\left(R^{2}=0.176, p<0.01\right)$, with peak expression at 1.2 years ( \pm 0.7 years). $\boldsymbol{B}$, Age-binned results for GluN2B expression. $\boldsymbol{C}$, Scatterplot of GluN2A expression across the lifespan fit with a weighted curve. $\boldsymbol{D}$, Age-binned results for GluN2A expression. Scatterplots, histograms, and significance levels plotted using the conventions described in Figure $1 .{ }^{* *} p<0.01 .{ }^{* *} p<0.001$.

GluN2A expression than infants $(p<0.001)$, young children $(p<0.01)$, teens $(p<0.01)$, and older adults $(p<0.001)$ (Fig. 3D).

NMDARs are tetrameric channels with diheteromeric nascent receptors comprised of GluN1/GluN2B that shift during development with the majority becoming triheteromers comprised of GluN1/GluN2A/GluN2B (Sheng et al., 1994). Because GluN1 is a component of all NMDARs, we normalized expression of GluN2A and GluN2B to the expression of GluN1 to determine whether high variability during childhood was driven by variability in the total pool of NMDARs. Normalizing with GluN1 expression reduced the variability for both GluN2A and GluN2B throughout childhood; it also enhanced the GluN2B peak in late childhood (Fig. $4 A, B$ ) and the GluN2A peak in adulthood (Fig. $4 C, D$ ). The GluN1 normalization, however, did not eliminate variability of GluN2A and GluN2B during childhood.

2A:2B balance: protracted change across the lifespan

Visual experience shifts the 2A:2B balance in favor of GluN2A (Quinlan et al., 1999a, b) and that regulates the synaptic modification threshold for engaging LTP versus LTD (Philpot et al., 2007). Because the $2 \mathrm{~A}: 2 \mathrm{~B}$ balance is a key mechanism regulating visual experience-dependent metaplasticity, we analyzed it for human V1 by calculating an index of 2A:2B expression for each case. Here we found an orderly progression from more GluN2B $<5$ years of age, to approximately balanced GluN2B and GluN2A during the teen years, to a peak with more GluN2A during adulthood, followed by a shift back to more GluN2B in aging (Fig. $5 A, B)$. These changes in the $2 \mathrm{~A}: 2 \mathrm{~B}$ balance were fit by a Gaussian function $\left(R^{2}=0.633, p<0.0001\right)$ that peaked at 35.9 years $( \pm 4.6$ years) (Fig. 5A). The binned results illustrate the progressive shift toward significantly more GluN2A in adulthood and then shifting back to GluN2B in aging (Fig. $5 B$ ). The orderly shift in the 2A:2B balance, especially through childhood, was somewhat surprising because the individual subunits showed a lot of variability at that stage. The low variability of the $2 \mathrm{~A}: 2 \mathrm{~B}$ index suggests that the balance between this pair of subunits, rather than the absolute amount of each, is a critical component for GluN2A and GluN2B regulation of developmental plasticity. Importantly, compared with animal models where the shift to GluN2A is complete by the end of the CP (Sheng et al., 1994; Quinlan et al., 1999a; Beston et al., 2010), the 2A:2B shift in human V1 continued for 25 years beyond the age for susceptibility of developing amblyopia (Lewis and Maurer, 2005). 


\section{A}

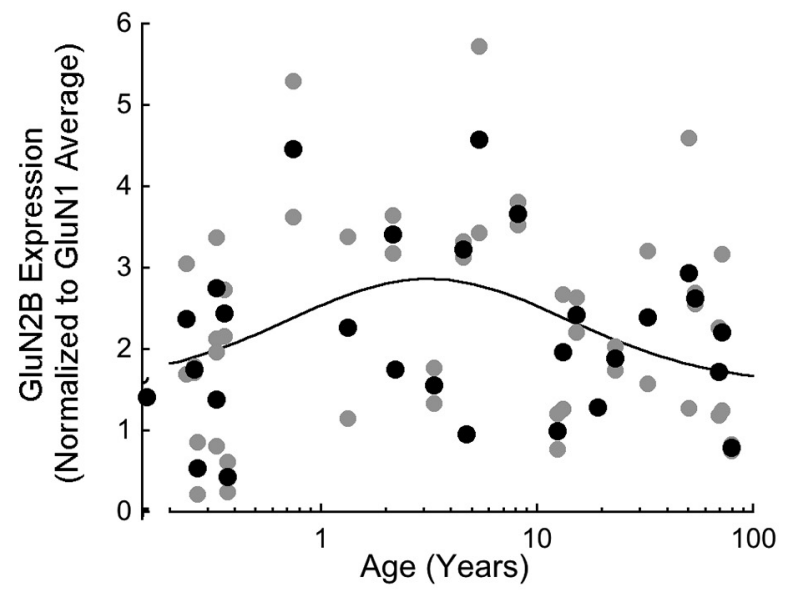

C

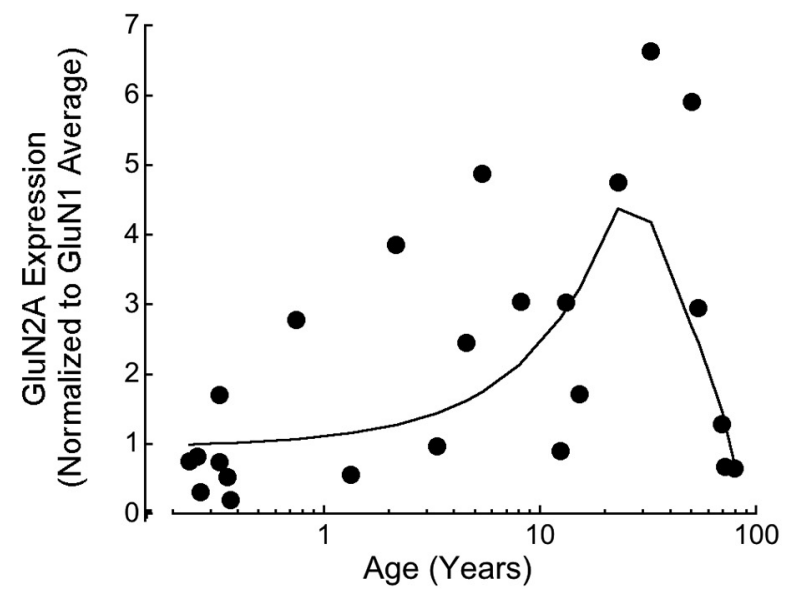

B $\quad 180 \mathrm{kDa}-\cdots---$

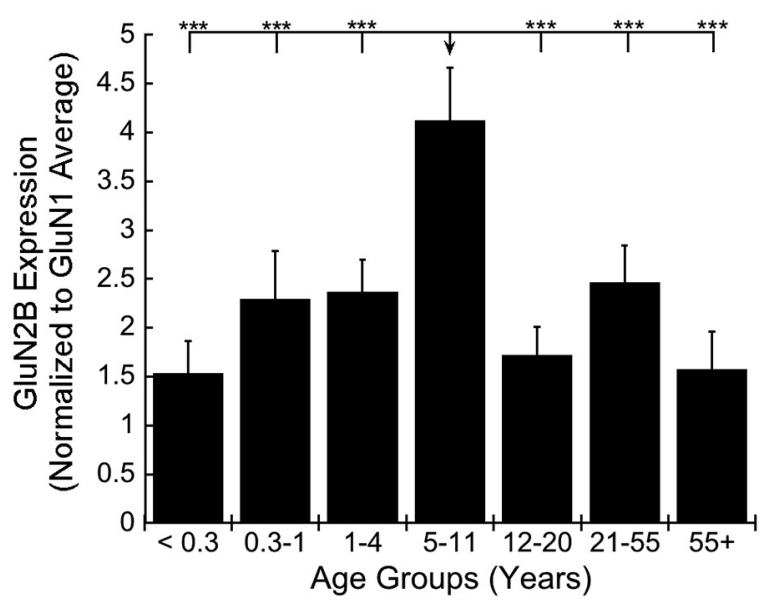

D

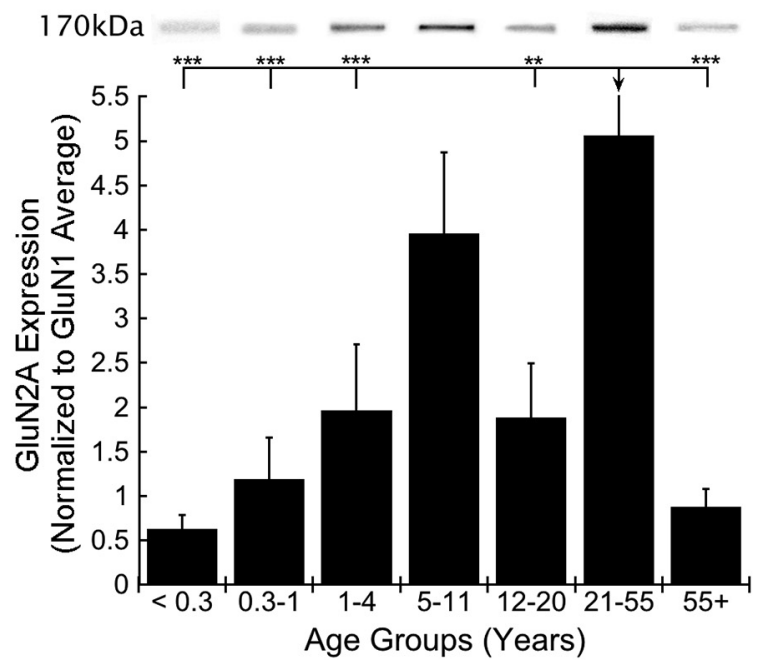

Figure 4. Development of GluN2B and GluN2A normalized to GluN1 in human V1. $A$, Scatterplot of GluN2B expression normalized to GluN1 across the lifespan fit with a Gaussian function $\left(R^{2}=\right.$ $0.106, p<0.05$ ), with peak expression at 3.2 years ( \pm 1.8 years). $\boldsymbol{B}$, Age-binned results for GluN2B normalized to GluN1 expression. $\boldsymbol{C}$, Scatterplot of GluN2A normalized to GluN1 expression across the lifespan fit with a weighted curve. $\boldsymbol{D}$, Age-binned results for GluN2A normalized to GluN1. Scatterplots, histograms, and significance levels plotted using the conventions described in Figure 1. ${ }^{* *} p<0.01$. ${ }^{* * *} p<0.001$.

A

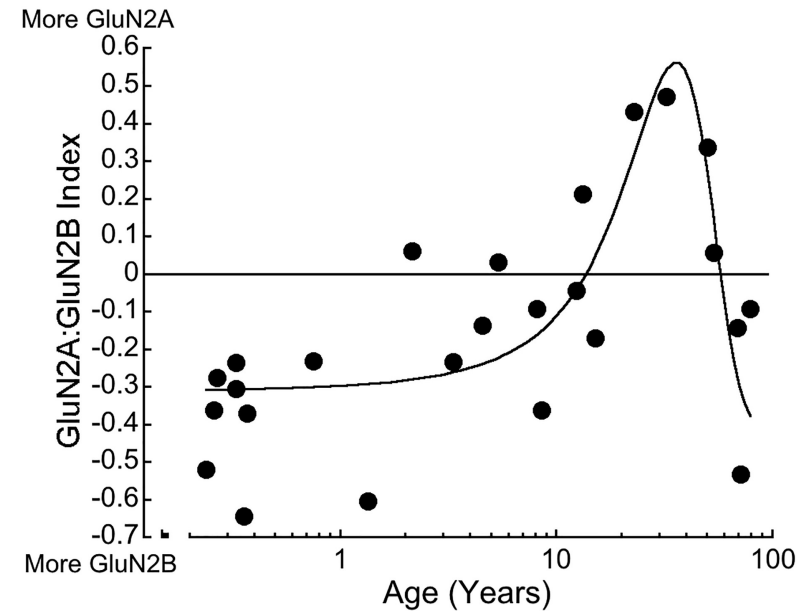

B

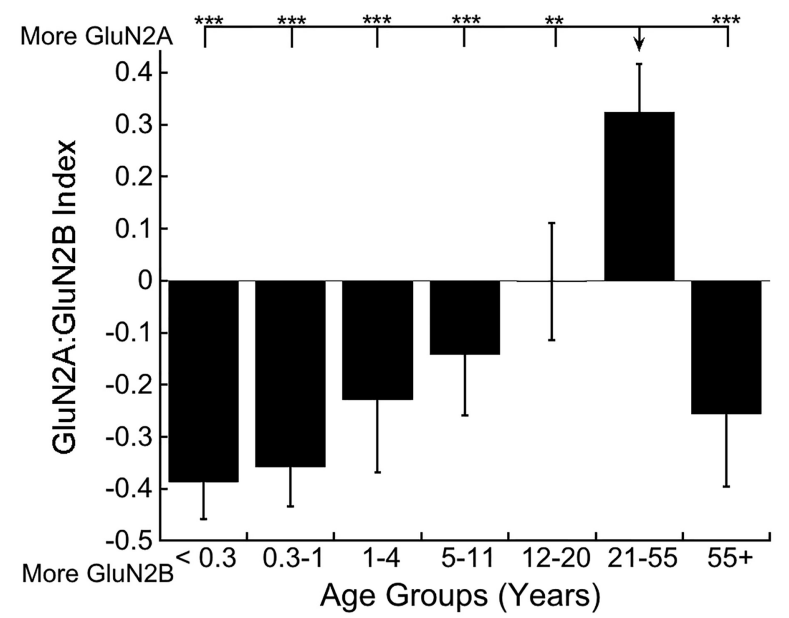

Figure 5. Development of the $2 A: 2 B$ balance ((GluN2A - GluN2B)/(GluN2A + GluN2B)) in human V1. $A$, Scatterplot of the $2 A: 2 B$ balance across the lifespan fit with a Gaussian function $\left(R^{2}=\right.$ $0.633, p<0.0001$ ), with peak expression at $\sim 35.9$ years of age ( \pm 4.6 years). $B$, Age-binned results for the 2A:2B balance. Scatterplot, histogram, and significance levels plotted using the conventions described in Figure 1. ${ }^{* *} p<0.01 .{ }^{* *} p<0.001$. 
A

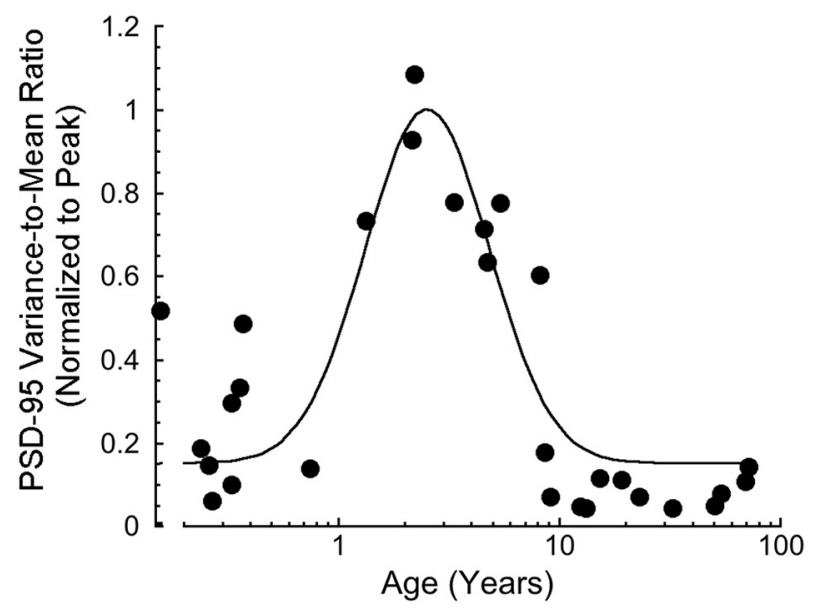

C

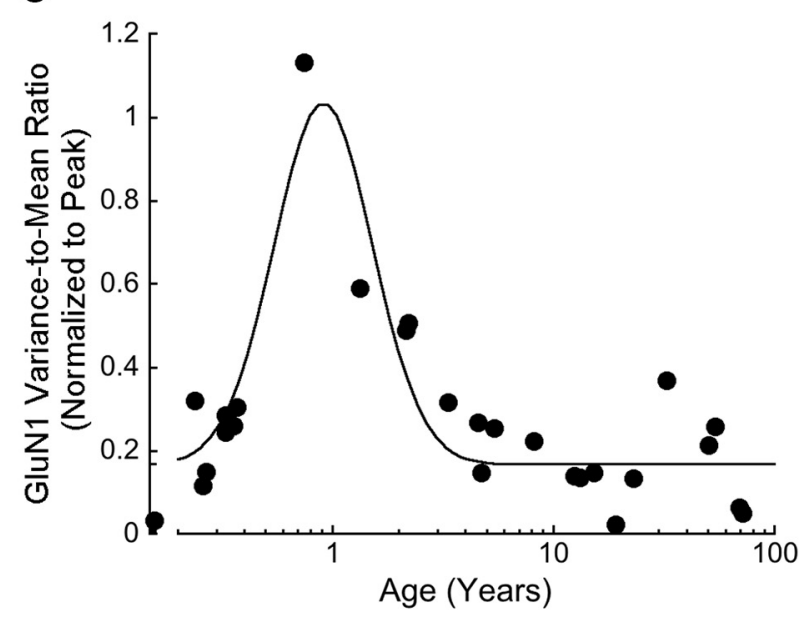

E

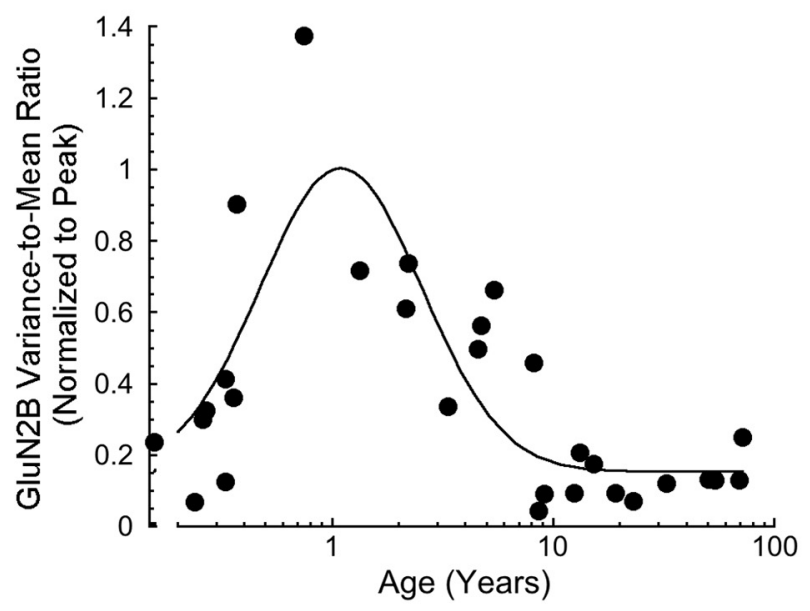

B

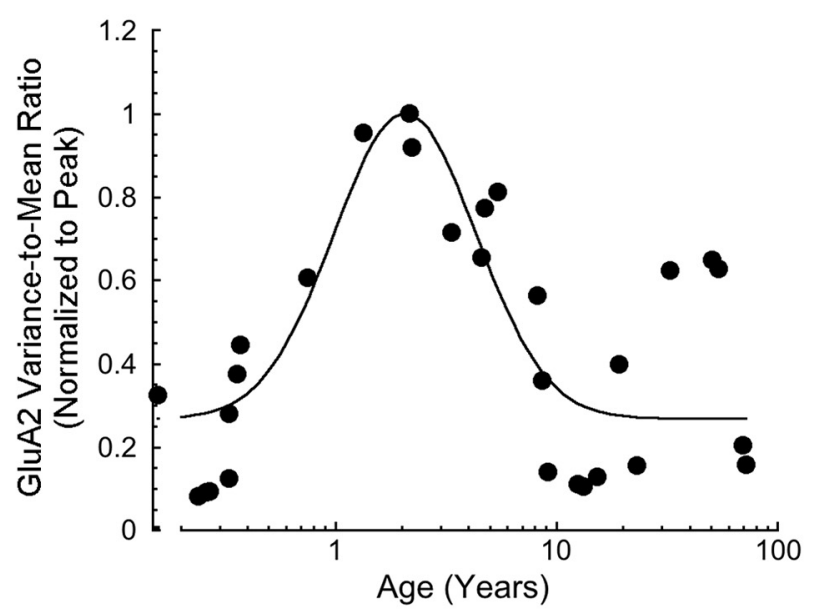

D

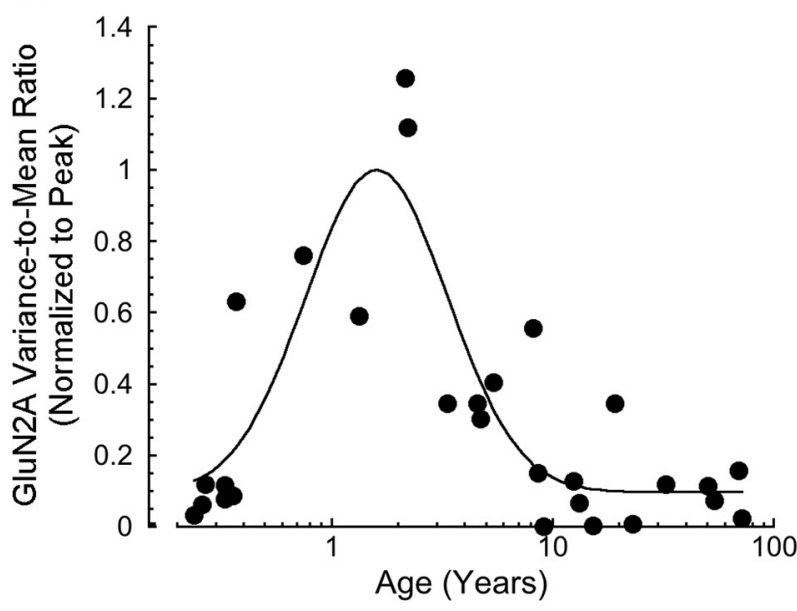

$\mathbf{F}$

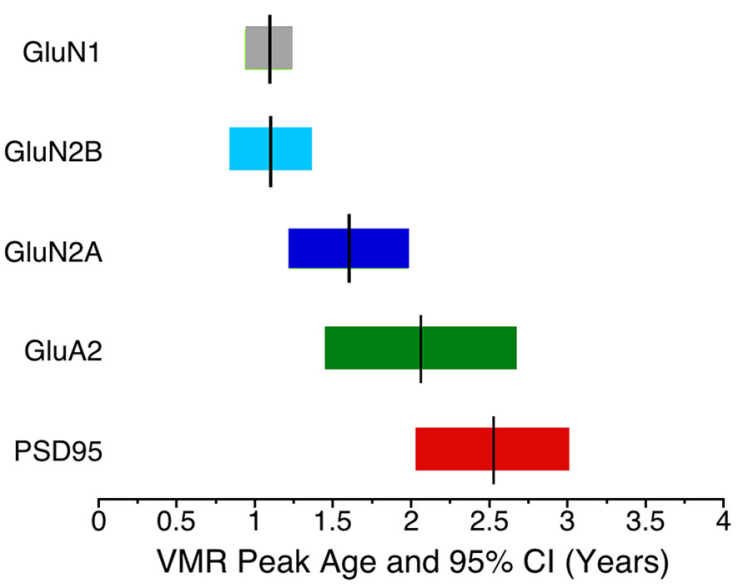

Figure 6. Development of the VMR for PSD-95, GluA2, GluN1, GluN2A, and GluN2B in human V1. Black dots indicate the VMR for a moving window of 3 cases. Each protein's scatterplot was fit with a Gaussian function, and the data were normalized to the peak of the function. $\boldsymbol{A}$, PSD-95 VMR peaked at 2.5 years ( \pm 0.5 years) $\left(R^{2}=0.778, p<0.0001\right) . B$, GluA2 VMR peaked at 2.1 years ( \pm 0.6 years) $\left(R^{2}=0.641, p<0.0001\right)$. C, GluN1 VMR peaked at 1.1 years $\left( \pm 0.2\right.$ years) $\left(R^{2}=0.8, p<0.0001\right)$. $D$, GluN2A VMR peaked at 1.6 years $( \pm 0.4$ years $)\left(R^{2}=0.694, p<0.0001\right)$. $E$, GluN2B VMR peaked at 1.1 years ( \pm 0.3 years) $\left(R^{2}=0.618, p<0.0001\right)$. $F$, Summary chart showing the progression of peaks of interindividual variability (vertical black line) and the $95 \% \mathrm{Cl}$ (colored bar) for each protein. 


\begin{tabular}{|c|c|c|c|c|c|c|}
\hline & & $\begin{array}{l}\text { Stage } 1 \\
\text { (<1 year) }\end{array}$ & $\begin{array}{c}\text { Stage } 2 \\
\text { (1-4 years) }\end{array}$ & $\begin{array}{c}\text { Stage } 3 \\
\text { (5-11 years) }\end{array}$ & $\begin{array}{c}\text { Stage } 4 \\
\text { (12-55 years) }\end{array}$ & $\begin{array}{c}\text { Stage } 5 \\
\text { (>55 years) }\end{array}$ \\
\hline \multirow{5}{*}{$\begin{array}{l}\text { Individual } \\
\text { Protein } \\
\text { Development }\end{array}$} & GluN1 & GluN1 & & & & \\
\hline & GluN2B & & & GluN2B & & \\
\hline & GluA2 & & & GluA2 & & \\
\hline & PSD-95 & & & PSD-95 & & \\
\hline & GluN2A & & & & GluN2A & \\
\hline
\end{tabular}

\begin{tabular}{c|c|c|c|c|c|}
\hline $\begin{array}{c}\text { Index } \\
\text { 2A:2B }\end{array}$ & GluN2B & & GluN2A & GluN2B \\
\hline Development & GluA2:GluN1 & GluN1 & GluA2 & & \\
\hline
\end{tabular}

\begin{tabular}{c|l|c|}
\hline Inter- & GluN1 & GluN1 \\
\hline $\begin{array}{c}\text { Individual } \\
\text { Variability }\end{array}$ & GluN2B & GluN2B \\
Waves & PSD-95 & GluA2 \\
\hline & GluN2A & PSD-95 \\
\hline
\end{tabular}

Figure 7. Summary of the five stages of development for the glutamatergic proteins. Changes for the individual glutamatergic proteins are illustrated with gray levels where black represents the maximum expression and lighter gray represents less expression. GluN1 peaked during the first year (Stage 1), GluN2B, GluA2, and PSD-95 in late childhood (Stage 3), and GluN2A at $\sim 40$ years (Stage 4) before declining in aging (Stage 5). Changes for the two indices (2A:2B, GluA2:GluN1) are color-coded. For the 2A:2B balance, red represents more GluN2B and green represents more GluN2A. For the AMPA:NMDA balance, red represents more GluN1 and green represents more GluA2. The shift to more GluN2A peaked in adulthood (Stage 4) and then returned to more GluN2B in aging (Stage 5). The switch to more GluA2 happened at $\sim 1$ year and continued until late childhood (Stage 3). The waves of interindividual variability for each protein are present, with dark blue representing maximum variability that occurred in young childhood (Stage 2 ) and lighter blue representing stages with low variability.

Waves of interindividual variability during childhood Many studies of human brain development and function have found large interindividual variations, including our studies of synaptic and nonsynaptic proteins in human V1. We analyzed interindividual variability and found waves of higher variability in childhood (Pinto et al., 2015; Siu et al., 2015). Here we applied the same approach and calculated the Fano factor to determine how the VMR changed across the lifespan for the current set of glutamatergic proteins.

We found that each glutamatergic protein had a wave of higher interindividual variability during childhood that was well fit by a Gaussian function (Fig. 6A-E). There was a progression in the peak age of interindividual variability (VMRs) that began with GluN1 and GluN2B at 1.1 years (GluN1, \pm 0.2 years, $R^{2}=$ $0.8, p<0.0001)\left(\right.$ GluN2B, \pm 0.3 years, $\left.R^{2}=0.618, p<0.0001\right)$, to GluN2A at 1.6 years ( \pm 0.4 years, $\left.R^{2}=0.694, p<0.0001\right)$, to GluA2 at 2.1 years ( \pm 0.6 years, $\left.R^{2}=0.641, p<0.0001\right)$, to PSD-95 at 2.5 years ( \pm 0.5 years, $R^{2}=0.778, p<0.0001$ ) (Fig. $6 A-E)$. We plotted the progression of peak ages for interindividual variability with their $95 \%$ CIs to show that variability occurred between 1 and 3 years of age, and the peaks started with GluN1 and GluN2B then progressed to GluN2A, GluA2, and ended with PSD-95 (Fig. 6F).

\section{Discussion}

Our results show that development of glutamatergic synaptic proteins in human $\mathrm{V} 1$ mirror changes in visual perception across the lifespan. Human visual perception matures in stages (Ellemberg et al., 1999; Kovács et al., 1999; Braddick et al., 2005; Owsley, 2011; Hartshorne and Germine, 2015), and the glutamate receptor proteins studied here revealed five stages of development (Fig. 7). Those stages can support structural maturation of the intrinsic network, visually driven plasticity, closure of the CP, synaptic stability, and degeneration in human V1. These results are similar to the maturation of GABAergic proteins in human V1 (Pinto et al., 2010) and suggest that synaptic changes in V1 are likely to impact visual perception and plasticity across the lifespan.

Glutamatergic proteins regulate fundamental aspects of excitatory neurotransmission (Cull-Candy et al., 1998), visual plasticity (Turrigiano, 2008; Yashiro and Philpot, 2008; Cooke and Bear, 2014; Turrigiano, 2017), and receptive field properties in V1 (Ramoa et al., 2001; Rivadulla et al., 2001; Fagiolini et al., 2004; Self et al., 2012). Quantification of these proteins by Western blotting is one of the few methods that can track the maturation of human V1 to link changes in synaptic function, network structure, and visual perception. Protein analysis, however, does not address the cell types, layers, and circuits that are changing. Nor does it separate presynaptic and postsynaptic NMDARs, which play different roles in neurotransmission and experiencedependent plasticity (Banerjee et al., 2016). The current results may provide a blueprint to focus anatomical and other studies of human V1 on key stages of development.

The five stages of glutamatergic protein development in human V1 are as follows:

Stage 1: the first year, structural maturation of the intrinsic network

Initially, GluN1 expression was high and then a rapid reduction at $\sim 1$ year caused a switch in the AMPA:NMDA balance to more GluA2. That pattern suggests initial dominance by NMDARcontaining silent synapses that are rapidly replaced by AMPARcontaining active synapses (Isaac et al., 1997; Rumpel et al., 1998). The loss of GluN1 at $\sim 1$ year coincides with a loss of the endocannabinoid receptor CB1 (Pinto et al., 2010); and because $\mathrm{CB} 1$ plays a central role in establishing excitatory connections (Harkany et al., 2008), the high levels of CB1 and GluN1 may contribute to the functional maturation of intracortical (Burkhalter et al., 1993) and intercortical connections (Burkhalter, 1993). 
We found that GluN2B dominated the 2A:2B balance throughout Stages 1-3. Many animal studies have shown that the 2A:2B balance contributes to developmental plasticity in V1 and emergence of visual function (Quinlan et al., 1999a; Erisir and Harris, 2003; Philpot et al., 2007; Cho et al., 2009; Smith et al., 2009; Durand et al., 2012). The dominance of GluN2B suggests that the synaptic modification threshold favors LTP (Philpot et al., 2007; Yashiro and Philpot, 2008), and V1 neurons are more receptive to potentiation of an open eye's inputs (Cho et al., 2009). This may explain why just $1 \mathrm{~h}$ of visual experience in an infant is enough to improve acuity of an eye treated for congenital cataracts (Maurer et al., 1999). Thus, this stage reflects the establishment of nascent excitatory synapses and initiation of plasticity in V1 circuits.

\section{Stage 2: young children (1-4 years), visually driven plasticity} During the second stage of V1 development, we found progressive increases in GluA2, PSD-95, and GluN2A, but the dominant feature was the wave of interindividual variability. The variability was similar to our previous findings for presynaptic (Synapsin, Synaptophysin), postsynaptic (Gephyrin, PSD-95), and a nonneuronal protein (Golli myelin basic protein, MBP) (Pinto et al., 2015; Siu et al., 2015). Variability peaking with GluN1 and GluN2B at $\sim 1$ year, GluN2A at $\sim 1.5$ years, GluA2 at $\sim 2$ years, and ending with PSD-95 at $\sim 2.5$ years. Those waves may reflect true interindividual variability in young children with cortical development taking off at different ages. The waves may also represent high levels of intraindividual variability driven by the dynamics of network states where expression of each synaptic protein could be high one day and low the next. Because the data here are cross-sectional, we cannot differentiate between these two ideas, but the implications for them on cortical development are different. For example, if the waves reflect ongoing dynamics then they could function similar to how feedback about the network state shifts processing of olfactory circuits in Caenorhabditis elegans (Gordus et al., 2015). In that model, environmental or other factors could modulate the state of synaptic plasticity. Rather than thinking about the waves as random or unpredictable, they may reveal a feature of visually driven plasticity needed to develop adaptive circuits that support visual processing.

\section{Stage 3: older children (5-11 years), closure of the critical period}

Expression of GluN2B, PSD-95, GluA2, and the AMPA:NMDA balance peaked in the third stage. These changes could end the CP for ocular dominance plasticity (Erisir and Harris, 2003; Huang et al., 2015). For example, in mouse V1, PSD-95 peaks at the end of the CP and consolidates AMPA-containing synapses (Huang et al., 2015). This stage also coincides with the end of susceptibility for children developing amblyopia (Epelbaum et al., 1993; Keech and Kutschke, 1995; Lewis and Maurer, 2005).

By the end of Stage 3, the 2A:2B balance was approximately equal. A shift to more GluN2A in V1 is driven by visual experience (Quinlan et al., 1999b), and the findings here show that the $2 \mathrm{~A}: 2 \mathrm{~B}$ shift begins in young children but is still not complete by the end of the $\mathrm{CP}$ for developing amblyopia. In contrast, the $2 \mathrm{~A}: 2 \mathrm{~B}$ shift in animal models is complete by the end of the CP (Sheng et al., 1994; Quinlan et al., 1999a; Beston et al., 2010). Perhaps the slow 2A:2B shift in combination with peak expression of GluA2 allows for strong engagement of both Hebbian and homeostatic forms of experience-dependent plasticity (Turrigiano, 2017).

\section{Stage 4: teens and young adults (12-55 years), synaptic stability}

Through teens and young adults, there was continued development as the $2 \mathrm{~A}: 2 \mathrm{~B}$ balance switched to favor GluN2A and peak expression of GluN2A did not occur until $\sim 40$ years. This may seem like surprisingly slow development for human V1, but it was comparable with the development of some GABAergic proteins (GAD65 and $\mathrm{GABA}_{\mathrm{A}} \alpha 1$ ) (Pinto et al., 2010) as well as cortical myelin (classic MBP) (Siu et al., 2015).

In mouse $\mathrm{V} 1$, the developmental shift to more GluN2A is slower for parvalbumin-positive $\left(\mathrm{PV}^{+}\right)$inhibitory interneurons than pyramidal neurons (Mierau et al., 2016). Perhaps the slow 2A:2B shift in human V1 reflects late maturation of $\mathrm{PV}^{+}$cells. Fast-spiking $\mathrm{PV}^{+}$cells also have GluA2-containing AMPARs (Kooijmans et al., 2014), so they are a site where changes in visual experience could activate inhibitory and excitatory aspects of short-term plasticity in human V1 (Lunghi et al., 2011, 2015a, b). Interestingly, blocking NMDARs prevents surround-suppression in monkey V1 (Self et al., 2012), and even a low dose of the noncompetitive NMDAR antagonist, ketamine, impairs the performance of human observers on a spatial integration task (Meuwese et al., 2013).

The late $2 \mathrm{~A}: 2 \mathrm{~B}$ shift is likely to adjust the synaptic modification threshold, making it more difficult for visual experience to engage LTP (Yashiro and Philpot, 2008). More GluN2A will also shorten the decay time of NMDARs (Stocca and Vicini, 1998; Vicini et al., 1998), even for triheteromeric receptors (Hansen et al., 2014). In addition, GluN2A-containing NMDARs are more stable in the synapse (Groc et al., 2006), and their activation promotes cell survival (Liu et al., 2007). These features of GluN2A-containing receptors suggest that this stage reflects a time of synaptic stability in human V1.

\section{Stage 5: aging ( $>55$ years), degeneration}

The last stage saw a dramatic $\sim 75 \%$ loss of GluN2A expression, bringing it back to levels found in infants ( $<1$ year of age). In contrast, there was no change in GluN2B expression so the $2 \mathrm{~A}: 2 \mathrm{~B}$ balance switched back to GluN2B in aging.

Age-related changes in human vision (Bennett et al., 2007; Betts et al., 2007) and monkey receptive field properties (Leventhal et al., 2003; Wang et al., 2005; Zhang et al., 2008) have been described as resulting from poor signal-to-noise caused by a loss of inhibition. Our previous study of GABAergic proteins in human V1 found a modest loss of GAD65 (Pinto et al., 2010), but that was much less than the loss of GuN2A found here. Because GluN2A-containing NMDARs are dense on $\mathrm{PV}^{+}$inhibitory interneurons in young mice (Mierau et al., 2016), the loss of GluN2A in aging human V1 may involve $\mathrm{PV}^{+}$cells.

The age-related 2A:2B shift to more GluN2B is likely to cause slower decay times and weaker conductances at NMDARs (CullCandy et al., 1998; Vicini et al., 1998; Hansen et al., 2014). It could also slide the synaptic modification threshold so that visual experience can more readily engage LTP. That plasticity, however, may come at the cost of higher metabolic stress, GluN2Bactivated excitotoxicity (Liu et al., 2007) and other vulnerabilities linked with NMDARs changes in aging (Magnusson et al., 2010). It is clear that the aging cortex does not simply become juvenilelike (Williams et al., 2010), and the specific loss of GluN2A found here could be a harbinger of degeneration in human V1.

In conclusion, the current results and our other investigations of human V1 show that synaptic and nonsynaptic proteins develop through a series of orchestrated stages that extend across the lifespan (Murphy et al., 2005; Pinto et al., 2010, 2015; Wil- 
liams et al., 2010; Siu et al., 2015). The glutamatergic proteins studied here are central players in visually driven plasticity, receptive field properties, and visual function. We found a late shift in the 2A:2B balance and a gradual maturation of GluA2. These findings will enable researchers to test the efficacy of specific neuroplasticity-based therapies at different stages of the lifespan.

\section{References}

Banerjee A, Larsen RS, Philpot BD, Paulsen O (2016) Roles of presynaptic NMDA receptors in neurotransmission and plasticity. Trends Neurosci 39:26-39. CrossRef Medline

Beaulieu C, Kisvarday Z, Somogyi P, Cynader M, Cowey A (1992) Quantitative distribution of GABA-immunopositive and -immunonegative neurons and synapses in the monkey striate cortex (area 17). Cereb Cortex 2:295-309. CrossRef Medline

Bennett PJ, Sekuler R, Sekuler AB (2007) The effects of aging on motion detection and direction identification. Vision Res 47:799-809. CrossRef Medline

Beston BR, Jones DG, Murphy KM (2010) Experience-dependent changes in excitatory and inhibitory receptor subunit expression in visual cortex. Front Synaptic Neurosci 2:138. CrossRef Medline

Betts LR, Sekuler AB, Bennett PJ (2007) The effects of aging on orientation discrimination. Vision Res 47:1769-1780. CrossRef Medline

Braddick O, Birtles D, Wattam-Bell J, Atkinson J (2005) Motion- and orientation-specific cortical responses in infancy. Vision Res 45:31693179. CrossRef Medline

Burkhalter A (1993) Development of forward and feedback connections between areas V1 and V2 of human visual cortex. Cereb Cortex 3:476-487. CrossRef Medline

Burkhalter A, Bernardo KL, Charles V (1993) Development of local circuits in human visual cortex. J Neurosci 13:1916-1931. Medline

Chen WS, Bear MF (2007) Activity-dependent regulation of NR2B translation contributes to metaplasticity in mouse visual cortex. Neuropharmacology 52:200-214. CrossRef Medline

Cho KK, Khibnik L, Philpot BD, Bear MF (2009) The ratio of NR2A/B NMDA receptor subunits determines the qualities of ocular dominance plasticity in visual cortex. Proc Natl Acad Sci U S A 106:5377-5382. CrossRef Medline

Christopoulos A, Lew MJ (2000) Beyond eyeballing: fitting models to experimental data. Crit Rev Biochem Mol Biol 35:359-391. CrossRef Medline

Cooke SF, Bear MF (2014) How the mechanisms of long-term synaptic potentiation and depression serve experience-dependent plasticity in primary visual cortex. Philos Trans R Soc B Biol Sci 369:20130284. CrossRef Medline

Cooper LN, Bear MF (2012) The BCM theory of synapse modification at 30: interaction of theory with experiment. Nat Rev Neurosci 13:798-810. CrossRef Medline

Cull-Candy SG, Brickley SG, Misra C, Feldmeyer D, Momiyama A, Farrant M (1998) NMDA receptor diversity in the cerebellum: identification of subunits contributing to functional receptors. Neuropharmacology 37: 1369-1380. CrossRef Medline

Dahlhaus M, Li KW, van der Schors RC, Saiepour MH, van Nierop P, Heimel JA, Hermans JM, Loos M, Smit AB, Levelt CN (2011) The synaptic proteome during development and plasticity of the mouse visual cortex. Mol Cell Proteomics 10:M110.005413. CrossRef Medline

Daw NW, Fox K, Sato H, Czepita D (1992) Critical period for monocular deprivation in the cat visual cortex. J Neurophysiol 67:197-202. Medline

Durand S, Patrizi A, Quast KB, Hachigian L, Pavlyuk R, Saxena A, Carninci P, Hensch TK, Fagiolini M (2012) NMDA receptor regulation prevents regression of visual cortical function in the absence of Mecp2. Neuron 76:1078-1090. CrossRef Medline

Ellemberg D, Lewis TL, Liu CH, Maurer D (1999) Development of spatial and temporal vision during childhood. Vision Res 39:2325-2333. CrossRef Medline

Epelbaum M, Milleret C, Buisseret P, Dufier JL (1993) The sensitive period for strabismic amblyopia in humans. Ophthalmology 100:323-327. CrossRef Medline

Erisir A, Harris JL (2003) Decline of the critical period of visual plasticity is concurrent with the reduction of NR2B subunit of the synaptic NMDA receptor in layer 4. J Neurosci 23:5208-5218. Medline

Fagiolini M, Katagiri H, Miyamoto H, Mori H, Grant SG, Mishina M, Hensch TK (2003) Separable features of visual cortical plasticity revealed by
N-methyl-D-aspartate receptor 2A signaling. Proc Natl Acad Sci U S A 100:2854-2859. CrossRef Medline

Fagiolini M, Fritschy JM, Löw K, Möhler H, Rudolph U, Hensch TK (2004) Specific GABAA circuits for visual cortical plasticity. Science 303:16811683. CrossRef Medline

Germine LT, Duchaine B, Nakayama K (2011) Where cognitive development and aging meet: face learning ability peaks after age 30 . Cognition 118:201-210. CrossRef Medline

Gordus A, Pokala N, Levy S, Flavell SW, Bargmann CI (2015) Feedback from network states generates variability in a probabilistic olfactory circuit. Cell 161:215-227. CrossRef Medline

Groc L, Heine M, Cousins SL, Stephenson FA, Lounis B, Cognet L, Choquet D (2006) NMDA receptor surface mobility depends on NR2A-2B subunits. Proc Natl Acad Sci U S A 103:18769-18774. CrossRef Medline

Hansen KB, Ogden KK, Yuan H, Traynelis SF (2014) Distinct functional and pharmacological properties of Triheteromeric GluN1/GluN2A/ GluN2B NMDA receptors. Neuron 81:1084-1096. CrossRef Medline

Harkany T, Mackie K, Doherty P (2008) Wiring and firing neuronal networks: endocannabinoids take center stage. Curr Opin Neurobiol 18: 338-345. CrossRef Medline

Hartshorne JK, Germine LT (2015) When does cognitive functioning peak? The asynchronous rise and fall of different cognitive abilities across the life span. Psychol Sci 26:433-443. CrossRef Medline

Hensch TK (2004) Critical period regulation. Annu Rev Neurosci 27:549579. CrossRef Medline

Heynen AJ, Yoon BJ, Liu CH, Chung HJ, Huganir RL, Bear MF (2003) Molecular mechanism for loss of visual cortical responsiveness following brief monocular deprivation. Nat Neurosci 6:854-862. CrossRef Medline

Huang X, Stodieck SK, Goetze B, Cui L, Wong MH, Wenzel C, Hosang L, Dong Y, Löwel S, Schlüter OM (2015) Progressive maturation of silent synapses governs the duration of a critical period. Proc Natl Acad Sci U S A 112:E3131-E3140. CrossRef Medline

Huntley GW, Vickers JC, Janssen W, Brose N, Heinemann SF, Morrison JH (1994) Distribution and synaptic localization of immunocytochemically identified NMDA receptor subunit proteins in sensory-motor and visual cortices of monkey and human. J Neurosci 14:3603-3619. Medline

Huttenlocher PR, de Courten C, Garey LJ, Van der Loos H (1982) Synaptogenesis in human visual cortex: evidence for synapse elimination during normal development. Neurosci Lett 33:247-252. CrossRef Medline

Isaac JT, Crair MC, Nicoll RA, Malenka RC (1997) Silent synapses during development of thalamocortical inputs. Neuron 18:269-280. CrossRef Medline

Keech RV, Kutschke PJ (1995) Upper age limit for the development of amblyopia. J Pediatr Ophthalmol Strabismus 32:89-93. Medline

Kim E, Sheng M (2004) PDZ domain proteins of synapses. Nat Rev Neurosci 5:771-781. CrossRef Medline

Kleinschmidt A, Bear MF, Singer W (1987) Blockade of "NMDA" receptors disrupts experience-dependent plasticity of kitten striate cortex. Science 238:355-358. CrossRef Medline

Kooijmans RN, Self MW, Wouterlood FG, Beliën JA, Roelfsema PR (2014) Inhibitory interneuron classes express complementary AMPA-receptor patterns in macaque primary visual cortex. J Neurosci 34:6303-6315. CrossRef Medline

Kovács I, Kozma P, Fehér A, Benedek G (1999) Late maturation of visual spatial integration in humans. Proc Natl Acad Sci U S A 96:12204-12209. CrossRef Medline

Lambo ME, Turrigiano GG (2013) Synaptic and intrinsic homeostatic mechanisms cooperate to increase L2/3 pyramidal neuron excitability during a late phase of critical period plasticity. J Neurosci 33:8810-8819. CrossRef Medline

Lee HG, Jo J, Hong HH, Kim KK, Park JK, Cho SJ, Park C (2016) State-ofthe-art housekeeping proteins for quantitative Western blotting: revisiting the first draft of the human proteome. Proteomics 16:1863-1867. CrossRef Medline

Levelt CN, Hübener M (2012) Critical-period plasticity in the visual cortex. Annu Rev Neurosci 35:309-330. CrossRef Medline

Leventhal AG, Wang Y, Pu M, Zhou Y, Ma Y (2003) GABA and its agonists improved visual cortical function in senescent monkeys. Science 300:812815. CrossRef Medline

Lewis TL, Maurer D (2005) Multiple sensitive periods in human visual development: evidence from visually deprived children. Dev Psychobiol 46: 163-183. CrossRef Medline 
Liu Y, Wong TP, Aarts M, Rooyakkers A, Liu L, Lai TW, Wu DC, Lu J, Tymianski M, Craig AM, Wang YT (2007) NMDA receptor subunits have differential roles in mediating excitotoxic neuronal death both in vitro and in vivo. J Neurosci 27:2846-2857. CrossRef Medline

Lunghi C, Burr DC, Morrone C (2011) Brief periods of monocular deprivation disrupt ocular balance in human adult visual cortex. Curr Biol 21: R538-R539. CrossRef Medline

Lunghi C, Berchicci M, Morrone MC, Di Russo F (2015a) Short-term monocular deprivation alters early components of visual evoked potentials. J Physiol 593:4361-4372. CrossRef Medline

Lunghi C, Emir UE, Morrone MC, Bridge H (2015b) Short-term monocular deprivation alters GABA in the adult human visual cortex. Curr Biol 25:1496-1501. CrossRef Medline

Magnusson KR, Brim BL, Das SR (2010) Selective vulnerabilities of $\mathrm{N}$-methyl-D-aspartate (NMDA) receptors during brain aging. Front Aging Neurosci 2:11. CrossRef Medline

Maurer D, Lewis TL, Brent HP, Levin AV (1999) Rapid improvement in the acuity of infants after visual input. Science 286:108-110. CrossRef Medline

Meuwese JD, van Loon AM, Scholte HS, Lirk PB, Vulink NC, Hollmann MW, Lamme VA (2013) NMDA receptor antagonist ketamine impairs feature integration in visual perception. PLoS One 8:e79326. CrossRef Medline

Mierau SB, Patrizi A, Hensch TK, Fagiolini M (2016) Cell-specific regulation of N-methyl-D-aspartate receptor maturation by Mecp2 in cortical circuits. Biol Psychiatry 79:746-754. CrossRef Medline

Murphy KM, Beston BR, Boley PM, Jones DG (2005) Development of human visual cortex: a balance between excitatory and inhibitory plasticity mechanisms. Dev Psychobiol 46:209-221. CrossRef Medline

Murphy KM, Balsor J, Beshara S, Siu C, Pinto JG (2014) A high-throughput semi-automated preparation for filtered synaptoneurosomes. J Neurosci Methods 235:35-40. CrossRef Medline

Owsley C (2011) Aging and vision. Vision Res 51:1610-1622. CrossRef Medline

Philpot BD, Sekhar AK, Shouval HZ, Bear MF (2001) Visual experience and deprivation bidirectionally modify the composition and function of NMDA receptors in visual cortex. Neuron 29:157-169. CrossRef Medline

Philpot BD, Espinosa JS, Bear MF (2003) Evidence for altered NMDA receptor function as a basis for metaplasticity in visual cortex. J Neurosci 23:5583-5588. Medline

Philpot BD, Cho KK, Bear MF (2007) Obligatory role of NR2A for metaplasticity in visual cortex. Neuron 53:495-502. CrossRef Medline

Pinto JG, Hornby KR, Jones DG, Murphy KM (2010) Developmental changes in GABAergic mechanisms in human visual cortex across the lifespan. Front Cell Neurosci 4:16. CrossRef Medline

Pinto JG, Jones DG, Williams CK, Murphy KM (2015) Characterizing synaptic protein development in human visual cortex enables alignment of synaptic age with rat visual cortex. Front Neural Circuits 9:3. CrossRef Medline

Quinlan EM, Olstein DH, Bear MF (1999a) Bidirectional, experiencedependent regulation of N-methyl-D-aspartate receptor subunit composition in the rat visual cortex during postnatal development. Proc Natl Acad Sci U S A 96:12876-12880. CrossRef Medline

Quinlan EM, Philpot BD, Huganir RL, Bear MF (1999b) Rapid, experiencedependent expression of synaptic NMDA receptors in visual cortex in vivo. Nat Neurosci 2:352-357. CrossRef Medline

Ramoa AS, Mower AF, Liao D, Jafri SI (2001) Suppression of cortical NMDA receptor function prevents development of orientation selectivity in the primary visual cortex. J Neurosci 21:4299-4309. Medline
Rivadulla C, Sharma J, Sur M (2001) Specific roles of NMDA and AMPA receptors in direction-selective and spatial phase-selective responses in visual cortex. J Neurosci 21:1710-1719. Medline

Rumpel S, Hatt H, Gottmann K (1998) Silent synapses in the developing rat visual cortex: evidence for postsynaptic expression of synaptic plasticity. J Neurosci 18:8863-8874. Medline

Scherzer CR, Landwehrmeyer GB, Kerner JA, Counihan TJ, Kosinski CM, Standaert DG, Daggett LP, Veliçelebi G, Penney JB, Young AB (1998) Expression of N-methyl-D-aspartate receptor subunit mRNAs in the human brain: hippocampus and cortex. J Comp Neurol 390:75-90. CrossRef Medline

Self MW, Kooijmans RN, Supèr H, Lamme VA, Roelfsema PR (2012) Different glutamate receptors convey feedforward and recurrent processing in macaque V1. Proc Natl Acad Sci U S A 109:11031-11036. CrossRef Medline

Sheng M, Cummings J, Roldan LA, Jan YN, Jan LY (1994) Changing subunit composition of heteromeric NMDA receptors during development of rat cortex. Nature 368:144-147. CrossRef Medline

Siu CR, Balsor JL, Jones DG, Murphy KM (2015) Classic and Golli Myelin Basic Protein have distinct developmental trajectories in human visual cortex. Front Neurosci 9:138. CrossRef Medline

Smith GB, Heynen AJ, Bear MF (2009) Bidirectional synaptic mechanisms of ocular dominance plasticity in visual cortex. Philos Trans R Soc B Biol Sci 364:357-367. CrossRef Medline

Stocca G, Vicini S (1998) Increased contribution of NR2A subunit to synaptic NMDA receptors in developing rat cortical neurons. J Physiol 507: 13-24. CrossRef Medline

Taylor G, Hipp D, Moser A, Dickerson K, Gerhardstein P (2014) The development of contour processing: evidence from physiology and psychophysics. Front Psychol 5:719. CrossRef Medline

Turrigiano GG (2008) The self-tuning neuron: synaptic scaling of excitatory synapses. Cell 135:422-435. CrossRef Medline

Turrigiano GG (2017) The dialectic of Hebb and homeostasis. Philos Trans R Soc B Biol Sci 372:20160258. CrossRef Medline

Turrigiano GG, Nelson SB (2004) Homeostatic plasticity in the developing nervous system. Nat Rev Neurosci 5:97-107. CrossRef Medline

Vicini S, Wang JF, Li JH, Zhu WJ, Wang YH, Luo JH, Wolfe BB, Grayson DR (1998) Functional and pharmacological differences between recombinant $\mathrm{N}$-methyl-D-aspartate receptors. J Neurophysiol 79:555-566. Medline

Wang Y, Zhou Y, Ma Y, Leventhal AG (2005) Degradation of signal timing in cortical areas V1 and V2 of senescent monkeys. Cereb Cortex 15:403408. CrossRef Medline

Williams K, Irwin DA, Jones DG, Murphy KM (2010) Dramatic loss of Ube3A expression during aging of the mammalian cortex. Front Aging Neurosci 2:18. CrossRef Medline

Yashiro K, Philpot BD (2008) Regulation of NMDA receptor subunit expression and its implications for LTD, LTP, and metaplasticity. Neuropharmacology 55:1081-1094. CrossRef Medline

Yoshii A, Sheng MH, Constantine-Paton M (2003) Eye opening induces a rapid dendritic localization of PSD-95 in central visual neurons. Proc Nat Acad Sci U S A 100:1334-1339. CrossRef Medline

Zhang J, Wang X, Wang Y, Fu Y, Liang Z, Ma Y, Leventhal AG (2008) Spatial and temporal sensitivity degradation of primary visual cortical cells in senescent rhesus monkeys. Eur J Neurosci 28:201-207. CrossRef Medline

Zilles K, Werners R, Büsching U, Schleicher A (1986) Ontogenesis of the laminar structure in areas 17 and 18 of the human visual cortex: a quantitative study. Anat Embryol 174:339-353. CrossRef Medline 